\title{
PERBEDAAN KEMAMPUAN PEMECAHAN MASALAH MATEMATIKA MENGGUNAKAN MODEL PEMBELAJARAN PROBLEM BASED LEARNING DAN DISCOVERY LEARNING DI KELAS VIII SMP NEGERI 1 PERCUT SEI TUAN
}

\author{
Rabithah Hasibuan ${ }^{1}$, Bornok Sinaga ${ }^{2}$ \\ ${ }^{1}$ FMIPA, Universitas Negeri Medan, Sumatera Utara, Indonesia \\ e-mail: rabithah.hasibuan95@gmail.com
}

\begin{abstract}
Abstrak
Penelitian ini bertujuan untuk mengetahui kemampuan pemecahan masalah matematika siswa dengan menggunakan model pembelajaran Problem Based Learning lebih baik daripada model pembelajaran Discovery Learning di kelas VIII SMP Negeri 1 Percut Sei Tuan. Penelitian ini merupakan penelitian eksperimen semu dengan desain pretest-posttest Control Group Design. Variabel penelitian ini terdiri dari variabel bebas yaitu penggunaan model pembelajaran Problem Based Learning dan Dicovery Learning, sedangkan variabel terikat yaitu kemampuan pemecahan masalah matematika siswa. Populasi dalam penelitian ini adalah seluruh siswa kelas VIII SMP Negeri 1 Percut Sei Tuan yang terdiri dari 8 kelas, sedangkan sampel dalam penelitian ini adalah siswa kelas VIII-G (kelas eksperimen I) sebanyak 31 orang dan kelas VIII-H (kelas eksperimen II) sebanyak 31 orang. Instrumen penelitian dalam pengumpulan data adalah tes dan lembar observasi. Sebelum pengujian hipotesis terlebih dahulu diuji normalitas data dengan menggunakan uji Liliefors dan homogenitas data menggunakan uji F. Dari pengujian yang dilakukan diperoleh bahwa hasil pretest kedua sampel berdistribusi normal dan homogen, dengan demikian penulis bisa memberikan perlakuan kepada kedua sampel. Dari hasil analisis data pretest-posttes dengan menggunakan uji-t pada taraf $\alpha=0,05$ diperoleh $t_{\text {hitung }}$ $>t_{\text {tabel }}$ yaitu 1,955 > 1,677sehingga $H_{0}$ ditolak dan $H_{a}$ diterima. Maka dapat disimpulkan bahwa kemampuan pemecahan masalah matematika siswa dengan menggunakan model pembelajaran Problem Based Learning lebih baik daripada model pembelajaran Discovery Learning di kelas VIII SMP Negeri 1 Percut Sei Tuan.
\end{abstract}

Kata kunci : Kemampuan pemecahan masalah, , model pembelajaran Problem Based Learning dan Discovery Learning.

\begin{abstract}
This study aims to determine the problem solving ability of mathematics students using Problem Based Learning model of learning is better than the model of learning Discovery Learning in class VIII SMP Negeri 1 Percut Sei Tuan. This research is a quasiexperimental research with pretest-posttest Control Group Design design. The variables of this study consisted of independent variables, namely the use of Problem Based Learning and Dicovery Learning, while the dependent variable is the students' math problem solving
\end{abstract}

Rabithah Hasibuan, Bornok Sinaga. Perbedaan Kemampuan Pemecahan Masalah Matematika Menggunakan Model Pembelajaran Problem Based Learning dan Discovery Learning di Kelas VIII SMP Negeri 1 Percut Sei Tuan. Inspiratif, Vol. 3. No. 1 April 2017. 
abilities. The population in this study is all students of class VIII SMP Negeri 1 Percut Sei Tuan consisting of 8 classes, while the sample in this study were students of class VIII-G (experiment class I) as many as 31 people and class VIII-H (Experiment class II) as many as 31 people. Research instruments in data collection are test and observation sheet. Before testing the hypothesis first tested the normality of data by using Liliefors test and homogeneity of data using $F$ test. From the test it was obtained that the pretest results of both samples distributed normal and homogeneous, thus the authors can provide treatment to both samples. From result of analysis of pretest-posttes data by using $t$-test at $\alpha=0,05$ obtained t count > ttable that is 1,955> 1,677 so that $H_{0}$ refused and $H_{a}$ accepted. Then it can be concluded that the problem solving ability of mathematics students using Problem Based Learning model is better than Discovery Learning model in class VIII SMP Negeri 1 Percut Sei Tuan.

Keywords: Problem solving abilities, Problem Based Learning and Discovery Learning model

\section{Pendahuluan}

Perkembangan IPTEK dewasa ini menuntut semua pihak untuk meningkatkan pendidikan sehingga memacu dunia pendidikan untuk berpola pikir cepat,cermat,tepat dan akurat sehingga diperlukan generasi penerus bangsa yang bermutu tinggi. Pendidikan merupakan bidang penting dalam menentukan kualitas suatu bangsa. Pendidikan dapat diterima dari lingkungan akademik maupun lingkungan masyarakat. Sekolah merupakan lingkungan akademik untuk memperoleh pendidikan formal. Pendidikan formal yaitu adanya mata pelajaran yang diberikan di sekolah tersebut dan diatur oleh kurikulum. Pendidikan akan terus berkembang seiring dengan perkembangan zaman seperti yang diungkapkan oleh Trianto (2011:1) bahwa :

pendidikan adalah salah satu bentuk perwujudan kebudayaan manusia yang dinamis dan sarat perkembangan. Oleh karena itu, perubahan atau perkembangan pendidikan adalah hal yang memang seharusnya terjadi sejalan dengan perubahan budaya kehidupan. Perubahan dalam arti perbaikan pendidikan pada semua tingkat perlu terus-menerus dilakukan sebagai antisipasi kepentingan masa depan.

Matematika adalah ilmu yang universal yang merupakan perkembangan teknologi modern. Matematika sebagai salah satu mata pelajaran dinilai cukup memegang peranan penting dalam membentuk siswa menjadi berkualitas,karena matematika suatu sarana berfikir untuk mengkaji sesuatu secara logis dan sistematik. Muller dan Burkhardt (2007:1) mengatakan bahwa "Matematika merupakan salah satu bagian terpenting dalam kurikulum setiap Negara, terutama karena matematika memiliki peran yang sangat penting dalam kehidupan, pekerjaan, dan digunakan juga untuk memecahkan masalah yang ada di mata pelajaran lain".

Dalam pembelajaran matematika, guru diharapkan dapat memampukan siswa menguasai konsep dan

Rabithah Hasibuan, Bornok Sinaga. Perbedaan Kemampuan Pemecahan Masalah Matematika Menggunakan Model Pembelajaran Problem Based Learning dan Discovery Learning di Kelas VIII SMP Negeri 1 Percut Sei Tuan. Inspiratif, Vol. 3. No. 1 April 2017. 
memecahkan masalah dengan kebiasaan berpikir kritis,logis,sistematis,dan terstruktur. National Council of Teacher Mathematics (NCTM) mengajukan, Problem solving must be the focus of school mathematics (Sobel dan Maletsky, 1988:53) Dengan demikian polya (1980) menyatakan, in my opini, the first duty of a teacher of mathematics is to use this opportunity: he should do everything in his power to develop his students'ability to solve problems.

Tuntuan kedua kutipan ini adalah pentingnya guru merencang dan menerapkan model pembelajaran matematika berdasarkan masalah,sehingga kompetensi dasar yang harus dimiliki setiap siswa adalah standart minimal tentang pengetahuan,keterampilan,sikap dan nilai-nilai yang terefleksi pada pembelajaran matematika dengan kebiasaan berfikir dan bertindak memecahkan masalah.

Tujuan pembelajaran matematika bukan untuk menjadikan semua siswa menjadi matematikawan tetapi untuk menjadikan siswa melek matematika. Berdasarkan standart dalam tujuan umum NCTM (Taylor, 1993, NCTM, 1991), terdapat 5 aspek untuk menyatakan siswa melek matematika, yaitu (1) belajar bernalar secara matematis (learning to reason mathematically); (2) terampil memecahkan masalah (becoming a mathematical problem solver); (3) belajar mengahargai matematika (learn to value mathematics); (4) menjadi percaya diri dengan kemampuan sendiri (becoming confident of one's ability); (5) belajar berkomunikasi secara matematis.

Berdasarkan jawaban siswa yang tertera pada gambar di atas diperoleh bahwa siswa belum memahami masalah, hal itu terlihat dari siswa yang tidak menuliskan apa yang diketahui dan ditanya, tidak merencanakan penyelesaian masalah atau menuliskan rumus yang digunakan, tidak menyelesaikan masalah, dan tidak memeriksa kembali jawaban serta memberikan kesimpulan. Dari hasil survei yang dilakukan peneliti dapat disimpulkan bahwa kemampuan pemecahan masalah matematika yang dimiliki oleh siswa masih sangat rendah.

Dengan demikian, diperlukan model pembelajaran yang efektif, membuat siswa lebih aktif dalam proses pembelajaran, lebih mudah menemukan dan memahami konsep-konsep yang sulit jika mereka saling mendiskusikan masalah yang ada dengan temannya. Salah satu model pembelajaran yang dapat digunakan adalah model pembelajaran kooperatif. Dengan model pembelajaran kooperatif, maka diharapkan dapat mengatasi kesulitan siswa dalam mempelajari matematika dan siswa dapat menemukan penyelesaian-penyelesaian masalah dari soal-soal pemecahan masalah di dalam kehidupan sehari-hari pada pokok bahasan kubus dan balok. Sehingga siswa akan termotivasi untuk belajar matematika dan mampu mengembangkan ide dan gagasan mereka dalam menyelesaikan permasalahan matematika.Trianto (2009: 57) menyatakan bahwa :

Tujuan pokok belajar kooperatif adalah memaksimalkan belajar siswa untuk peningkatan prestasi akademik dan pemahaman baik secara individu maupun secara kelompok. Karena siswa bekerja dalam suatu team, maka dengan sendirinya dapat memperbaiki hubungan di antara para siswa dari berbagai latar belakang etnis dan kemampuan, mengembangkan keterampilanketerampilan proses kelompok dan pemecahan masalah. Dari hasil tes dapat

Rabithah Hasibuan, Bornok Sinaga. Perbedaan Kemampuan Pemecahan Masalah Matematika Menggunakan Model Pembelajaran Problem Based Learning dan Discovery Learning di Kelas VIII SMP Negeri 1 Percut Sei Tuan. Inspiratif, Vol. 3. No. 1 April 2017. 
disimpulkan bahwa masih banyak siswa yang mengalami kesulitan dalam menyelesaikan soal matematika sehingga penalaran matematik siswa belum dapat meningkat seperti yang diharapkan guru.

Hal ini menggambarkan penalaran matematika bermasalah, maka perlu adanya suatu tindakan untuk dapat melatih dan mengembangkan kemampuan penalaran matematika siswa agar dapat meningkat dalam pembelajaran matematika. Trianto (2011: 1) menyatakan bahwa salah satu masalah pokok dalam pembelajaran pada pendidikan formal (sekolah) dewasa ini adalah masih rendahnya daya serap peserta didik. Faktor internal adalah faktor yang ada pada diri sendiri meliputi kemampuan dasar, baik kemampuan dasar umum (kecerdasan), maupun kemampuan dasar khusus (bakat), kesiapan untuk melakukan kegiatan dalam proses pembelajaran , minat untuk melakukan suatu kegiatan tertentu, pengalaman belajar yang telah dimiliki sebelumnya, dan kemampuan atau motivasi untuk belajar. Sedangkan faktor eksternal adalah faktor yang datang dari luar diri meliputi semua upaya yang dilakukan oleh guru, baik dalam memberikan rangsangan, bimbingan, pengarahan dan dorongan untuk terjadinya proses belajar.

Sehingga tidak hanya siswa yang dapat menyebabkan kemampuan siswa kurang dalam pemahaman matematika, tetapi guru dan lingkungan juga berpengaruh. Guru dapat mengurangi masalah ini dengan memberikan strategi pembelajaran inovatif yang mengembangkan kemampuan siswa. Salah satunya adalah dengan memberikan learning by doing dalam proses belajar mengajar. Surya (2010)

Melihat kondisi diatas, maka diperlukan suatu model pembelajaran yang dapat memfasilitasi kebutuhan proses kegiatan belajar mengajar yang melatih kemampuan pemecahan masalah matematika siswa, Misalnya dengan menggunakan model pembelajaran Discovery Learning dan model pembelajaran Problem Based Learning (PBL). Model pembelajaran Discovery Learning dan PBL merupakan model pembelajaran yang sama-sama bertujuan untuk meningkatkan daya tarik siswa dalam pemecahan masalah

Model Problem Based Learning (PBL) menurut Ward dalam Ngalimun (2014:89) merupakan salah satu model pembelajaran inovatif yang dapat memberikan kondisi belajar aktif kepada siswa. Sedangkan menurut Padmavathy dan Maaresh (2013:47) “ PBL menggambarkan kegiatan belajar di mana dengan adanya masalah mendorong pembelajaran. Artinya, pembelajaran dimulai dengan masalah yang harus diselesaikan, dan masalah yang diajukan adalah sedemikian rupa sehingga siswa perlu mendapatkan pengetahuan baru sebelum mereka dapat memecahkan masalah. Sejalan dengan hal tersebut, Regehr dan Norman dalam (Mansor dkk. 2014:261) menyatakan "PBL didasarkan pada asumsi bahwa belajar bukanlah proses penerimaan, melainkan, konstruksi pengetahuan baru ".

PBL adalah suatu model pembelajaran yang melibatkan siswa untuk memecahkan suatu masalah melalui tahap-tahap metode ilmiah sehingga siswa dapat mempelajari pengetahuan yang berhubungan dengan masalah tersebut dan sekaligus memiliki keterampilan untuk memecahkan masalah.

Selain itu, menurut Ibrahim sebagaimana yang dikutip Hosnan (2014: 295) , PBL meliputi pengajuan pertanyaan atau masalah, memusatkan

Rabithah Hasibuan, Bornok Sinaga. Perbedaan Kemampuan Pemecahan Masalah Matematika Menggunakan Model Pembelajaran Problem Based Learning dan Discovery Learning di Kelas VIII SMP Negeri 1 Percut Sei Tuan. Inspiratif, Vol. 3. No. 1 April 2017. 
pada keterkaitan antardisiplin, penyelidikan autentik, kerja sama dan menghasilkan karya serta peragaan. Sehingga dengan menerapkan model pembelajaran PBL ini, siswa benarbenar diajak berperan aktif dalam proses pembelajaran dan mengasah keterampilan siswa dalam memecahkan maslah matematika. Surya (2009) menyatakan pembelajaran kooperatif dengan berbasis masalah dapat memecahkan masalah matematika dan kehidupan sehari-hari.

Sedangkan Model pembelajaran Discovery Learning menekankan kepada aktivitas siswa secara maksimal untuk mencari dan menemukan, artinya discovery learning menempatkan siswa sebagai subjek belajar. Dalam proses pembelajaran, siswa tidak hanya berperan sebagai penerima pelajaran melalui penjelasan guru secara verbal, tetapi mereka berperan untuk menemukan sendiri inti dari materi pelajaran itu sendiri. Seperti yang diungkapkan Gulo (dalam Trianto, 2011:166) bahwa: Discovery learning adalah suatu rangkaian kegiatan belajar yang melibatkan secara maksimal seluruh kemampuan siswa untuk mencari dan menyelidiki secara sistematis, kritis, logis dan analitis sehingga mereka dapat merumuskan sendiri penemuannya dengan penuh percaya diri.

Sedangkan Renesse dan Ecke (2015:3) mendefinisikan pembelajaran Discovery learning dalam pendidikan memiliki karakteristik sebagai berikut: (1)Kegiatan utama pembelajaran, baik di dalam maupun di luar kelas, adalah pemecahan masalah. (2) Proses Belajar berpusat pada Siswa. (3) Guru bertindak sebagai fasilitator bukannya pemberi informasi pengetahuan. (4) Siswa menggunakan refleksi serta komunikasi yang aktif, baik secara lisan dan tertulis, untuk menambah pengetahuan yang sudah ada dengan pengetahuan baru.

Dengan menerapkan model discovery learning diharapkan siswa aktif dan kreatif menemukan sendiri. Siswa mampu merekonstruksi pengetahuan matematika berdasarkan pengalaman sendiri . Disamping itu, memberikan kesempatan kepada siswa untuk menerapkan ide-idenya dan belajar sesuai dengan gaya belajar mereka sendiri untuk memecahkan masalah matematika yang dihadapi oleh siswa tersebut.

Sedangkan Materi Kubus dan Balok adalah materi yang sangat banyak digunakan dalam keadaan sehari-hari dan materi ini sangat mendukung untuk dilakukannya model pembelajaran Problem Based Learning dan Discovery Learning. Hal ini disebabkan kedua model pembelajaran menggunakan keadaan yang ada dalam kehidupan sehari-hari. Dengan menerapkan model pembelajaran Problem Based Leaning (PBL) dan Discovery Learning yang menggunakan keadaan nyata sebagai objek pembelajaran, pengeteahuan siswa akan semakin lekat didalam diri siswa tersebut.

\section{Hipotesis Penelitian}

Berdasarkan rumusan masalah dan tujuan penelitian, yang menjadi hipotesis dalam penelitian ini dirumuskan sebagai berikut:

Kemampuan pemecahan masalah matematika yang dibelajakan dengan model pembelajaran problem based learning lebih baik dari kemampuan pemecahan masalah matematika yang dibelajarkan dengan pembelajaran discovery learning pada materi kubus dan balok di kelas VIII SMP Negeri 1 Percut Sei Tuan.

Rabithah Hasibuan, Bornok Sinaga. Perbedaan Kemampuan Pemecahan Masalah Matematika Menggunakan Model Pembelajaran Problem Based Learning dan Discovery Learning di Kelas VIII SMP Negeri 1 Percut Sei Tuan. Inspiratif, Vol. 3. No. 1 April 2017. 


\section{Metode Penelitian \\ 1.Jenis Penelitian}

Jenis penelitian yang digunakan adalah penelitian eksperimen semu (quasi experiment).

\section{Tempat dan Waktu Penelitian}

Penelitian ini dilaksanakan di SMP

Negeri 1 Percut Sei Tuan,waktu penelitian dilakukan pada semester II .

\section{Populasi dan Sampel Penelitian}

Populasi dalam penelitian ini adalah seluruh siswa kelas VIII SMP Negeri 1 Percut Sei Tuan T.A 2016/2017 dengan sampel dalam penelitian ini terdiri dari 2 kelas sebagai kelas eksperimen 1 dan kelas eksperimen 2 yang berjumlah masing-masing kelas 31 siswa.

\section{Desain penelitian}

Desain penelitian ini adalah pretestposttest only control group design.

Tabel 1. Desain Penelitian

\begin{tabular}{|c|r|c|r|}
\hline Kelas & Pretest & Perlakuan & Postest \\
\hline Eksp 1 & $\mathrm{T}_{1 \mathrm{x}}$ & $\mathrm{P}_{1}$ & $\mathrm{~T}_{2 \mathrm{x}}$ \\
\hline Eksp 2 & $\mathrm{T}_{1 \mathrm{y}}$ & $\mathrm{P}_{2}$ & $\mathrm{~T}_{2 \mathrm{y}}$ \\
\hline
\end{tabular}

Pada desain ini, pengelompokan sampel penelitian dilakukan secara acak, kelas eksperimen 1 diberi perlakuan pembelajaran Problem based learning $\left(\mathrm{P}_{1}\right)$ dan kelas eksperimen 2 diberi perlakuan pembelajaran Discovery learning $\left(\mathrm{P}_{2}\right)$, sebelum dilakukan perlakuan kepada kedua kelas masing-masing diberikan pretes dan sesudah perlakuan diberi posttest

\section{Instrumen Penelitian}

Instrumen penelitian ini menggunakan tes kemampuan pemecahan masalah matematika sebanyak 5 soal berbentuk uraian dimana setiap soal mengandung setiap indikator pemecahan masalah matematika.

\section{Analisis Data}

Analisis data penelitian ini adalah uji Liliefors, uji F, dan uji t.

\section{Hasil dan Pembahasan \\ Hasil Penelitian}

Sebelum dilakukannya penelitian, tes yang akan diberikan kepada sampel terlebih dahulu divalidkan kepada tiga validator yaitu kepada dua dosen matematika UNIMED yaitu Ibu Sri Lestari manurung, M.Pd, Ibu Erlinawaty Simanjuntak S.Pd, M.Si, dan guru bidang studi matematika di SMP Negeri 1 Percut Sei Tuan yaitu Ibu Rianti, S.Pd

\section{Deskripsi Hasil Kemampuan pemecahan masalah matematika pada Kelas Eksperimen 1 dan Kelas Eksperimen 2}

Dalam penelitian ini data yang diolah adalah nilai pretest dan posttest siswa yang dilakukan dikedua kelas yaitu kelas eksperimen I dengan pembelajaran problem based learning dan kelas eksperimen II dengan menggunakan pembelajaran discovery learning Setelah kedua kelas diberi perlakuan yang berbeda diberikan pretest untuk mengetahui kemampuan pemecahan masalah matematika siswa. Soal yang dipakai adalah soal berbentuk uraian yang berjumlah 5 butir soal. Sebelum soal tersebut diberikan, dilakukan validasi soal kepada 3 orang ahli dan semua soal valid sehingga soal layak dipakai.

\section{Deskripsi Hasil Kelas Eksperimen 1 dan Kelas Eksperimen 2}

Dari hasil pretes diperoleh rata-rata pretes kelas eksperimen I dengan model

Rabithah Hasibuan, Bornok Sinaga. Perbedaan Kemampuan Pemecahan Masalah Matematika Menggunakan Model Pembelajaran Problem Based Learning dan Discovery Learning di Kelas VIII SMP Negeri 1 Percut Sei Tuan. Inspiratif, Vol. 3. No. 1 April 2017. 
pembelajaran problem based learning adalah 19,419 dan rata-rata posttest adalah 28,354, dapat dilihat dari gambar diagram dibawah peningkatan siswa dari perlakuan pretest ke perlakuan posttest.

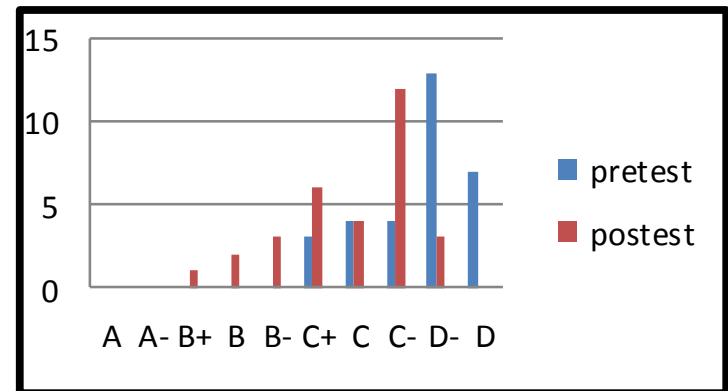

Gambar 1. Hasil Pretes dan Post Tes

Selanjutnya kelas eksperimen II dengan model pembelajaran discovery learning rata-rata pretest adalah 19,387. Dan rata-rata posttes 27,516.

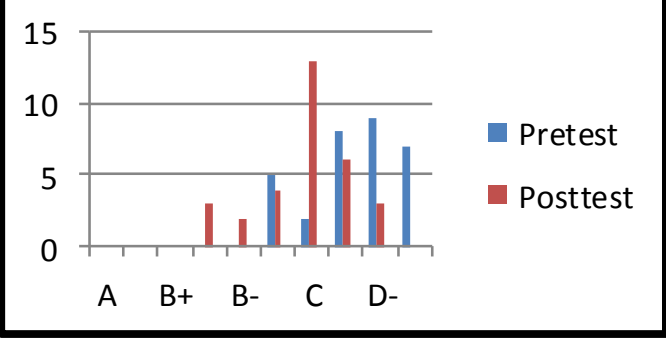

Gambar 2. Hasil Rata-rata Pretes dan

\section{Post Test}

Dapat dilihat dari hasil rata-rata kedua kelas tersebut maka kedua kelas sama selanjutnya dilakukan perlakuan untuk mengetahui kemampuan pemecahan masalah matematika siswa. Soal yang diberikan sebanyak 5 butir soal.

\section{* Analisis Data \\ $>$ Uji Normalitas Data}

Salah satu persyaratan analisis yang harus dipenuhi sebelum melakukan uji statistik parametrik adalah sebaran data kedua sampel harus berdistribusi normal. Untuk mengetahui sebaran data berdistribusi normal atau tidak dapat dilakukan uji normalitas dengan menggunakan uji Liliefors dengan syarat normal yang harus dipenuhi adalah $\mathrm{L}_{\text {hitung }}<\mathrm{L}_{\text {tabel }}$ pada taraf $\alpha=0,05$.

Secara ringkas hasil uji normalitas data Pretest dan postes kedua kelas diperlihatkan pada tabel berikut.

Tabel 2. Hasil Uji Normalitas

\begin{tabular}{|l|l|l|l|l|}
\hline Data & Kelas & $\mathrm{L}_{\text {hitung }}$ & $\mathrm{L}_{\text {tabel }}$ & Ket \\
\hline Pretest & Eksp 1 & 0,0204 & 0,1591 & Normal \\
\hline Pretest & Eksp 2 & 0,0395 & 0,1591 & Normal \\
\hline Postes & Eksp 1 & 0,0969 & 0,1591 & Normal \\
\hline Postes & Eksp 2 & 0,1192 & 0,1591 & Normal \\
\hline
\end{tabular}

Dari tabel di atas, terlihat bahwa data tes pretes dan data postes dari kedua kelas sampel yaitu kelas siswa yang belajar dengan model pembelajaran problem based learning dan model pembelajaran discovery learning memiliki sebaran data yang berdistribusi normal pada taraf signifikansi $\alpha=0,05$ dimana $\mathrm{L}_{\text {hitung }}<\mathrm{L}_{\text {tabel }}$.

\section{$>$ Uji Homogenitas Data}

Pengujian homogenitas data diuji menggunakan uji $F$ yang bertujuan untuk mengetahui kehomogenan varians data-data kelompok sampel penelitian. Data masing-masing kelompok sampel dinyatakan memiliki varians yang homogen, apabila nilai $\mathrm{F}_{\text {hitung }}<\mathrm{F}_{\text {tabel }}$ pada taraf $\alpha=0,05$. Secara ringkas hasil perhitungan uji homogenitas data kedua kelas diperlihatkan pada tabel berikut.

Tabel 3. Hasil Uji Homogenitas

\begin{tabular}{|c|l|c|c|l|}
\hline No & Data & $\mathbf{F}_{\text {hîtung }}$ & $\mathbf{F}_{\text {tabel }}$ & Ket \\
\hline 1 & pretes & 1,029 & 2,38 & Homogen \\
\hline 2 & Postes & 1,209 & 2,38 & Homogen \\
\hline
\end{tabular}

Dari tabel di atas tampak bahwa untuk data pretes dan data postes kedua kelas sampel memiliki $\mathrm{F}_{\text {hitung }}<\mathrm{F}_{\text {tabel }}$. Jadi $H_{0}: \mu_{1} \leq \mu_{2}$ diterima dan $H_{a}: \mu_{1}>$ $\mu_{2}$ ditolak. Sehingga data pretes dan data postes kelompok siswa yang diajar

Rabithah Hasibuan, Bornok Sinaga. Perbedaan Kemampuan Pemecahan Masalah Matematika Menggunakan Model Pembelajaran Problem Based Learning dan Discovery Learning di Kelas VIII SMP Negeri 1 Percut Sei Tuan. Inspiratif, Vol. 3. No. 1 April 2017. 
dengan model pembelajaran problem based learning dan model pembelajaran discovery learning memiliki varians yang sama besar.

\section{$>$ Uji Hipotesis}

Setelah diketahui kedua kelas sampel berdistribusi normal dan mempunyai varians yang sama besar, baik pretes maupun postes dan berasal dari populasi yang homogen, selanjutnya dilakukan uji hipotesis dengan menggunakan uji t, hal ini dilakukan untuk mengetahui apakah hipotesis penelitian diterima atau ditolak.

Pengujian hipotesis yang dilakukan pada data postes, diuji statistik satu pihak dengan cara membandingkan ratarata postes antara kelas eksperimen I dan kelas eksperimen II.

Hipotesis penelitian ini adalah:

$H_{o}$ : Kemampuan pemecahan masalah matematika siswa yang diajar dengan model pembelajaran problem based learning tidak lebih baik dibandingkan dengan siswa yang diajar dengan model pembelajaran discovery learning di kelas VIII SMP Negeri 1 Percut Sei Tuan

$H_{a}$ : Kemampuan pemecahan masalah matematika siswa yang diajar dengan model pembelajaran problem based learning lebih baik dibandingkan dengan siswa yang diajar dengan model pembelajaran discovery learning di kelas VIII SMP Negeri 1 Percut Sei Tuan

Tabel 4. Data Post Tes Hasil Penelitian

\begin{tabular}{|c|c|c|c|c|}
\hline \multirow{2}{*}{\multicolumn{2}{|c|}{\begin{tabular}{l|l} 
& \multicolumn{1}{|c}{$\bar{X}$} \\
Kelas & Kelas \\
Eksp 1 & Eksp 2 \\
\end{tabular}}} & \multirow[b]{2}{*}{$\mathbf{t}_{\text {hitung }}$} & \multirow[b]{2}{*}{$t_{\text {tabel }}$} & \multirow[b]{2}{*}{ Ket } \\
\hline & & & & \\
\hline 28,35 & 27,41 & 1,955 & 1,677 & $\begin{array}{l}\text { Terima } \\
\mathrm{H}_{\mathrm{a}}\end{array}$ \\
\hline
\end{tabular}

Dari data postes di atas diperoleh $\mathrm{t}_{\text {hitung }}=1,955$ dan $\mathrm{t}_{\text {tabel }}=1,677$ dengan $\alpha=0,05 \mathrm{dan} \mathrm{dk}=60$ dengan kriteria pengujian tolak $H_{o}$ jika $\mathrm{t}_{\text {hitung }}>\mathrm{t}_{\text {tabel }}$, untuk harga t lainnya $H_{o}$ diterima. Ini berarti bahwa $H_{o}$ ditolak dan $H_{a}$ diterima karena 1,955 > 1,677 sehingga diperoleh kesimpulan bahwa kemampuan pemecahan masalah matematika siswa yang diajar dengan model pembelajaran problem based learning lebih baik dibandingkan dengan siswa yang diajar dengan model pembelajaran discovery learning di kelas VIII SMP Negeri 1 Percut Sei Tuan.

\section{Pembahasan}

Penelitian yang dilakukan di SMP Negeri 1 Percut Sei Tuan ini menggunakan dua model pembelajaran yang berbeda yaitu Problem Based Learning (PBL) dengan Discovery Learning. Model pembelajaran Problem Based Leraning diterapkan di kelas VIII-G (eksperimen I) yang terdiri dari 31 siswa dan model pembelajaran Discovery Learning diterapkan di kelas VIII-H (eksperimen II) yang terdiri dari 31 siswa.

Hasil penelitian menunjukkan bahwa kemampuan pemecahan masalah siswa dengan menggunakan model pembelajaran Problem Based Learning lebih baik dibandingkan dengan kemampuan pemecahan masalah siswa dengan menggunakan model pembelajaran Discovery Learning, hal ini dapat dilihat dari rata-rata skor kelas eksperimen 1 sebesar 28,354 dengan jumlah siswa yang tuntas yaitu 22 siswa dari 31 siswa, sedangkan rata-rata skor kelas eksperimen 2 sebesar 27,516.

Berdasarkan nilai rata-rata postest tersebut sudah nampak perbedaan kemampuan pemecahan masalah kedua

Rabithah Hasibuan, Bornok Sinaga. Perbedaan Kemampuan Pemecahan Masalah Matematika Menggunakan Model Pembelajaran Problem Based Learning dan Discovery Learning di Kelas VIII SMP Negeri 1 Percut Sei Tuan. Inspiratif, Vol. 3. No. 1 April 2017. 
kelas sampel. Peneliti melihat bahwa pada kemampuan pemecahan masalah matematika dengan menggunakan model pembelajaran Problem Based Learning maupun Discovery Learning sama-sama dapat meningkatkan keaktifan siswa dalam pembelajaran matematika. Perbedaannya model pembelajaran Problem Based Learning merupakan teknik yang baik dalam merangsang siswa untuk lebih aktif dan berpikir kritis karena siswa diberikan kesempatan untuk mencari sendiri pemecahan masalah dengan kerjasama kelompok sehingga mereka lebih mudah memahami materi. Model pembelajaran ini merupakan sebuah varian diskusi kelompok dengan ciri khasnya adalah guru memberikan suatu permasalahan seperti LAS dan siswa dapat mengerjakan maalah tersebut dengan kelompok lalu perwakilan siswa dituntut untuk mempresentasikan hasil kelompok. Dengan begitu seluruh siswa akan terlibat total dari pembelajaran.

Dalam pembelajaran Problem Based Learning diperlukan tahap orientasi masalah, mengorganisasi peserta didik, membimbing penyelidikan, menyajikan hasil, mengevaluasi pemecahan masalah. Sedangkan model pembelajaran Discovery Learning melibatkan siswa untuk antusias dalam kelompok karena dalam hal ini kelompok dituntut untuk menemukan hasil. konsep dasar materi diterangkan langsung oleh guru lalu siswa mengerjakan LAS secara berkelompok.

Dari pengujian yang dilakukan terhadap postes diperoleh bahwa kedua kelas homogen. Kemudian dilakukan pengujian hipotesis untuk kemampuan pemecahan masalah matematika dengan menggunakan uji-t. Setelah dilakukan pengujian data, ternyata diperoleh hasil pengujian kemampuan pemecahan masalah matematika siswa pada taraf $\alpha=0,05, \mathrm{t}_{\text {hitung }}>\mathrm{t}_{\text {tabel }}$ yaitu $1,955>$ 1,677 maka $H_{o}$ ditolak dan $H_{a}$ diterima. Dengan demikian dapat disimpulkan bahwa kemampuan pemecahan masalah matematika siswa yang diajar dengan model pembelajaran problem based learning lebih baik dibandingkan dengan siswa yang diajar dengan model pembelajaran discovery learning.

Model pembelajaran Problem

Based Learning tidak mengharapkan siswa hanya sekedar mendengarkan, mencatat, kemudian menghafal materi pelajaran, akan tetapi melalui model pembelajaran Problem Based Learning siswa akan aktif berpikir, berkomunikasi, mencari, mengolah data dan akhirnya menyimpulkan.Ngalimun (2014:204) juga berpendapat bahwa “" Problem Based Learning (PBL) adalah suatu model pembelajaran yang melibatkan siswa untuk memecahkan suatu masalah melalui tahap-tahap metode ilmiah sehingga siswa dapat mempelajari pengetahuan yang berhubungan dengan masalah tersebut dan sekaligus memiliki keterampilan untuk memecahkan masalah".

Sementara discovery learning merupakan model pembelajaran yang dikembangkan berdasarkan pandangan kontruktivisme. Menurut Bruner, sebagaimana dikutip oleh Balim (2009: 2), mengajari siswa dengan dugaan penemuan, berpikir kritis, menanya, dan pemecahan masalah adalah salah satu prinsip pembelajaran science dan tekonologi. Dasar dari pembelajaran science adalah memahami bahwa fenomena alami dan sifat alam memerlukan penyelidikan dan penemuan. Penyelidikan dalam science terdiri dari percobaan dan penyelidikan fenomena alami dengan discovery learning.

Rabithah Hasibuan, Bornok Sinaga. Perbedaan Kemampuan Pemecahan Masalah Matematika Menggunakan Model Pembelajaran Problem Based Learning dan Discovery Learning di Kelas VIII SMP Negeri 1 Percut Sei Tuan. Inspiratif, Vol. 3. No. 1 April 2017. 
Meskipun demikian, baik problem based learning maupun discovery learning ternyata sama-sama dapat meningkatkan kemampuan pemecahan masalah matematika siswa di kedua kelas tersebut pada materi kubus dan balok.Tetapi rata-rata hasil post test kelas problem based learning lebih baik dibandingkan dengan kelas discovery learning.

Hal ini juga sejalan dengan pendapat (Peterson, 2004) "Inti pembelajaran mandiri dalam konteks ini adalah untuk promosikan pengumpulan informasi dengan mengidentifikasi apa yang pelajar sudah tahu, apa yang pelajar perlu ketahui, dan bagaimana mengisi celah itu mendukung posisi teoretis tertentu dengan bukti penelitian, satu ditinggalkan dengan satu dari dua pilihan, meninggalkan teori dan usaha penelitian, atau memilih atau menyusun teori alternatif yang membantu untuk menjelaskan bukti penelitian yang dikumpulkan". Dari sudut pandang teoretis, landasan saat ini untuk pembelajaran berbasis masalah, konstruktivisme Dewey, mengemukakan bahwa "pembelajaran berbasis masalah harus mengarah pada perolehan pengetahuan yang hebat dan penerapan pengetahuan yang lebih efektif'.Tetapi bukti penelitian sampai saat ini menunjukkan bahwa ini hanya setengah benar. Pembelajaran berbasis masalah tidak lagi efektif, dan dalam beberapa kasus kurang efektif, dalam mempromosikan perolehan pengetahuan daripada pendekatan pendidikan berbasis kuliah tradisional. Di sisi lain, pembelajaran berbasis masalah lebih efektif daripada pengajaran tradisional berbasis kuliah dalam mempromosikan aplikasi pengetahuan dan pemecahan masalah, seperti Dewey konstruktivis hal ini menunjukkan serangkaian hasil pembelajaran yang berbeda. Pergeseran sederhana dalam teori Penekanan dari pendekatan Dewey ke pendekatan Montomon untuk memahami pembelajaran berbasis masalah mengarah pada rekonseptualisasi pembelajaran berbasis masalah yang lebih sesuai dengan bukti empiris. Pergeseran penekanan ini menunjukkan bahwa ukuran keberhasilan pembelajaran berbasis masalah harus difokuskan pada berbagai aspek aplikasi dan permasalahan pengetahuan pemecahan bukan akuisisi pengetahuan. Hal ini mengarah langsung pada implikasi untuk penelitian lebih lanjut dan pengembangan kurikuler berkaitan dengan pembelajaran berbasis masalah dan kelas manajemen. Dalam hal ini bahwa problem based learning atau pembelajaran berbasis masalah lebih efektif dibandingkan pembelajaran tradisional atau konvensional. Hal ini juga sudah didukung dengan teori yang ada seperti teori Dewey.

Kemampuan pemecahan masalah matematika siswa dipengaruhi oleh cara mengajar guru atau model pembelajaran yang digunakan oleh guru. Semakin sesuai model pembelajaran yang digunakan semakin baik pula hasilnya. Penelitian ini menggunakan dua tipe model pembelajaran yang berbeda yaitu Problem Based Learning (PBL) dan inkuiri. Padmavathy dan Maaresh (2013:47) “ PBL menggambarkan kegiatan belajar di mana dengan adanya masalah mendorong pembelajaran. Artinya, pembelajaran dimulai dengan masalah yang harus diselesaikan, dan masalah yang diajukan adalah sedemikian rupa sehingga siswa perlu mendapatkan pengetahuan baru sebelum mereka dapat memecahkan masalah. Sedangkan Sedangkan Renesse dan Ecke (2015:3) mendefinisikan pembelajaran Inkuiri dalam pendidikan memiliki karakteristik sebagai berikut:

Rabithah Hasibuan, Bornok Sinaga. Perbedaan Kemampuan Pemecahan Masalah Matematika Menggunakan Model Pembelajaran Problem Based Learning dan Discovery Learning di Kelas VIII SMP Negeri 1 Percut Sei Tuan. Inspiratif, Vol. 3. No. 1 April 2017. 
(1) Kegiatan utama pembelajaran, baik di dalam maupun di luar kelas, adalah pemecahan masalah. (2) Proses Belajar berpusat pada Siswa. (3) Guru bertindak sebagai fasilitator bukannya pemberi informasi pengetahuan. Sehingga kedua model mendorong keterlibatan siswa secara aktif dalam kegiatan pembelajaran dan maningkatkan kemampuan pemecahan masalah matematika siswa.

Dari pembahasan di atas, adanya teori belajar yang mendukung dan penelitian yang relevan yang peneliti jelaskan di atas disimpulkan bahwa model pembelajaran problem based learning lebih baik dibandingkan dengan model pembelajaran discovery learning.

\section{Kesimpulan}

Berdasarkan hasil penelitian dan pengolahan data maka dapat ditarik kesimpulan sebagai berikut:

Kemampuan pemecahan masalah siswa yang dibelajarkan menggunakan model pembelajaran Problem Based Learning lebih baik daripada kemampuan pemecahan masalah siswa yang dibelajarkan menggunakan model pembelajaran Discovery Learning. Hal ini berdasarkan hasil pengujian hipotesis diperoleh nilai $\mathrm{t}_{\text {hitung }}=1,955$ dan $\mathrm{t}_{\text {tabel }}=$ 1,677 dengan $\mathrm{dk}=60$ dan taraf signifikan $\alpha=0,05$ sehingga terlihat $t_{\text {hitung }}>t_{\text {tabel }}$ yaitu $1,955>1,677$ yang berarti bahwa $\mathrm{H}_{\mathrm{o}}$ ditolak dan $\mathrm{H}_{\mathrm{a}}$ diterima.

\section{Daftar Pustaka}

Balim, A. G., (2009), The Effects of Discovery Learning on Students' Success and Inquiry
Learning Skills, Egitim Arastirmalaria-Eurasian

Journal of Educational Research, 35, 1-20.

Hosnan, M. (2014). Pendekatan Saintifik dan Kontekstual dalam Pembelajaran Abad 21. Bogor : Ghalia Indonesia.

Mansor, A.N., Abdullah, N.O., Wahab, J.A., Rasul, M.S., Nor, M.Y.M., Nor, N.M., dan Raof, R.A.Managing.,(2015)

Problem-Based Learning: Challenges and Solution for Educational Practice. Asian Social Science; Vol. 11, No. 4; 2015 ISSN 1911-2017 E-ISSN 1911-2025, 2013.

Muller, Eric, dan Burkhardt, H. 2007.Application And Modelling For Mathematics.

Ngalimun. 2014.Strategi dan Model Pembelajaran. Yogyakarta : Aswaja Pressindo

Padmavathy, R.D, dan K, Maaresh.Effectiveness of Problem Based Learning In Mathematics. International Multidisciplinary e-Journal. ISSN 2277-4262, 2013. Permendikbud,(2014),Pedoma n Penskoran Pemecahan Masalah Matematik.

Peterson, S.,(2004), Problem based learning and management development Empirical and theoretical considerations, Journal 13, 249-259

Renesse, C.V., dan Ecke, V.InquiryBased Learning and the Art of

Rabithah Hasibuan, Bornok Sinaga. Perbedaan Kemampuan Pemecahan Masalah Matematika Menggunakan Model Pembelajaran Problem Based Learning dan Discovery Learning di Kelas VIII SMP Negeri 1 Percut Sei Tuan. Inspiratif, Vol. 3. No. 1 April 2017. 
Mathematical Discourse. PRIMUS. Vol. 25. Issue 3.

Sinaga, B.(2007). Pengembangan Model Pembelajaran Matematika Berdasarkan Masalah Berbasis Budaya Batak (PBM-B3). Disertasi: $\quad$ PPs.Universitas Negeri Surabaya

Surya, E. (2009). Pembelajaran Kooperatif dengan Pendekatan Berbasis Masalah Dalam Pemecahan Masalah Matematika. Jurnal Pendidikan Matematika dan Sains, 4 (1), 1417.

Surya, E. 2010. Visual Thinking dalam Memaksimalkan Pembelajaran
Matematika Siswa Dapat

Membangun Karakter Bangsa.

Abmas UPI Bandung, Tahun 10

Nomor 10 Oktober 2010

Trianto., (2011), Mendesain Model Pembeajaran Inovatif-Progresif, Penerbit Kencana, Jakarta

Trianto, (2009), Mendesain Model Pembelajaran InovatifProgresif: Konsep, Landasan, dan Implementasinya pada Kurikulum Tingkat Satuan Pendidikan (KTSP), Kencana Prenada Media Group, Jakarta.

\section{${ }^{1}$ Rabithah Hasibuan}

${ }^{2}$ BornokSinaga

Rabithah Hasibuan, Bornok Sinaga. Perbedaan Kemampuan Pemecahan Masalah Matematika Menggunakan Model Pembelajaran Problem Based Learning dan Discovery Learning di Kelas VIII SMP Negeri 1 Percut Sei Tuan. Inspiratif, Vol. 3. No. 1 April 2017. 